\title{
Pengembangan Budaya Literasi Agama di SMA Negeri 2 Kediri
}

\author{
Maimunatun Habibah ${ }^{1}$ \\ ${ }^{1}$ Madrasah Aliyah Sunan Ampel Kediri \\ ${ }^{1}$ maimunatunhabibah@gmail.com
}

\begin{abstract}
The National Literacy Movement (GLN) programmed since 2016 has experienced developments with the emergence of many studies on literacy and literacy programs in schools. Literacy programs are not limited to literacy but also lead to religious literacy. This study seeks to raise the religious literacy program at SMA Negeri 2 Kediri. Based on field research carried out under the light of the Prothero religious literacy concept which was later developed by Gallagher, the study finds that the practice of religious literacy in SMA Negeri 2 Kediri has being carried out through a program of reading the scriptures according to their respective religions guided by the religious literacy reading team. The implementation process takes place through three stages. First, the school principal forms a religious literacy team. Second, the implementation phase which includes the stages of habituation, development, and learning. Third, the assessment stage. The three implementation processes are intended so that the religious literacy program not only leads to the accumulation of knowledge, but slowly increases to the level of daily practice.
\end{abstract}

Keywords: Religious Literacy, School Culture.

\begin{abstract}
Abstrak
Gerakan Literasi Nasional (GLN) yang diprogramkan sejak 2016 telah mengalami perkembangan dengan munculnya banyak kajian tentang literasi maupun program-program literasi di sekolah. Program literasi pun tidak terbatas pada baca-tulis tetapi juga mengarah pada literasi agama. Kajian ini berupaya mengangkat program literasi agama di SMA Negeri 2 Kediri. Berdasarkan penelitian lapangan yang dilakukan di bawah terang konsep literasi agama Prothero yang kemudian dikembangkan Gallagher, penelitian ini menemukan bahwa praktik literasi agama di SMA Negeri 2 Kediri dilakukan melalui program membaca kitab suci sesuai agama masingmasing dengan dipandu tim literasi membaca religius. Proses implementasinya berlangsung melalui tiga tahapan. Pertama, kepala sekolah membentuk tim literasi religius. Kedua, tahap pelaksanaan yang mencakup tahap pembiasaan, pengembangan, dan pembelajaran. Ketiga, tahap penilaian. Ketiga proses implementasi tersebut dimaksudkan agar program literasi agama tidak hanya mengarah pada akumulasi pengetahuan, tapi secara perlahan meningkat pada level praktik keseharian.
\end{abstract}

Kata Kunci: Budaya Sekolah, Literasi Agama. 


\section{Pendahuluan}

Tingkat literasi siswa masih terbilang rendah. Indikasinya tampak pada hasil survey Programme for International Student Assessment (PISA) 2018 yang menunjukkan skor Indonesia dalam kemampuan membaca sebesar 371 poin, sedangkan skor rata-rata Organisation for Economic Co-operation and Development (OECD) adalah 487. ${ }^{1}$ Pada periode putaran sebelumnya, yaitu PISA 2015 skor kemampuan membaca adalah 397 dengan skor rata-rata OECD sebesar 493. ${ }^{2}$ Hasil PISA 2018 menunjukkan dengan jelas bahwa siswa Indonesia mengalami penurunan kemampuan membaca dibandingkan dengan PISA 2015, ini juga berarti kompetensi membaca siswa Indonesia masih tergolong rendah.

Berkenaan dengan problem itu, Kementerian Pendidikan dan Kebudayaan telah menginisiasi pembentukan kelompok kerja Gerakan Literasi Nasional (GLN) sejak tahun 2016 yang mencakup tiga unit kerja yaitu Gerakan Literasi Masyarakat (GLM), Gerakan Literasi Sekolah (GLS), dan Gerakan Literasi Keluarga (GLK). GLN juga terus melakukan perbaikan dan penajaman konsep serta prosedur implementasi literasi dengan menyediakan buku panduan dan dokumen berupa desain induk pada masingmasing unit kerja. ${ }^{3}$ Ini berarti GLN amat serius menggerakkan program literasi dengan berupaya menghimpun dan mengoordinasikan seluruh elemen dengan melibatkan semua pihak (siswa, keluarga, masyarakat) untuk mengembangkan dan membudayakan literasi di Indonesia.

Sejak munculnya GLN, beberapa akademisi tampak mulai lebih intens melakukan kajian atau riset mengenai literasi pada berbagai elemen. Dalam hal ini, hasil riset Gustini, Rohaniawati dan Imani menekankan tentang pentingnya pengembangan program budaya literasi yang dilakukan secara berkelanjutan dan menjalin kerjasama dengan pemerintah provinsi terkait. ${ }^{4}$ Penelitian lain dilakukan oleh Sari dan Pujiono yang menemukan bahwa budaya literasi membaca maupun menulis mahasiswa Fakultas Bahasa dan Seni Universitas Negeri Yogyakarta masih tergolong rendah dan kurang maksimal. Sehingga diperlukan pembiasaan literasi yang dimulai dengan melakukan

\footnotetext{
${ }^{1}$ OECD, PISA 2018 Results (Volume I): What Students Know and Can Do, PISA (OECD, 2019), https://doi.org/10.1787/5f07c754-en.

${ }^{2}$ OECD, PISA 2015 Results (Volume I): Excellence and Equity in Education, PISA (OECD, 2016), https://doi.org/10.1787/9789264266490-en.

3"Tentang GLN | Gerakan Literasi Nasional,” accessed November 27, 2019, https://gln.kemdikbud.go.id/glnsite/tentang-gln/.

${ }^{4}$ Neng Gustini, Dede Rohaniawati, and Anugrah Imani, Budaya Literasi (Model Pengembangan Budaya Baca Tulis Berbasis Kecerdasan Majemuk Melalui Tutor Sebaya) (Yogyakarta: Deepublish, 2016).
} 
kreasi dan inovasi pelaksanaan perkuliahan. ${ }^{5}$ Dalam konteks sekolah riset Agustin dan Cahyono menyimpulkan bahwa di SMA Negeri 1 Geger GLS telah menunjukkan gaungnya dan secara perlahan elemen sekolah juga menampakkan kepeduliannya. Di mana penerapannya berlangsung pada awal KBM yaitu sebelum jam pelajaran pertama dimulai. Pada setiap kelas juga telah tersedia jurnal membaca yang dimaksudkan untuk mengetahui progress literasi siswa. ${ }^{6}$ Selanjutnya dalam konteks perguruan tinggi Yamin menegaskan bahwa penguatan budaya literasi menjadi penting karena akan berkontribusi pada produktifitas publikasi ilmiah. ${ }^{7}$

Selain dalam konteks pendidikan, kajian literasi di Indonesia juga tengah menyentuh aspek agama dan masyarakat. Kajian Iswanto mengenai praktik literasi agama pada manuskrip Cirebon menjadi salah satu rujukan penting dalam tulisan ini. Studinya menggunakan perspektif kajian literasi baru (new literacy studies) yang mencakup dua pembedaaan yaitu peristiwa literasi (literacy events) dan praktik literasi (literacy practices). Dalam kajiannya Iswanto menemukan sponsorship dalam naskahnaskah Cirebon khususnya naskah-naskah koleksi Elang Hilman, yaitu institusi keraton dengan raja hingga keturunannya dan pesantren sebagai sponsor utama. Dengan begitu, sponsorship literasi agama terjadi melalui kerjasama antara kalangan istana dan pesantren. Iswanto juga menginformasikan bahwa sejarah literasi Nusantara tidak melulu harus merujuk pada kesaksian kolonial karena senyatanya naskah yang tersebar di berbagai wilayah Nusantara dapat dijadikan acuan dalam penulisan sejarah praktik literasi Indonesia. ${ }^{8}$ Selanjutnya adalah riset Yetri, Iqbal dan Amaliah yang menemukan bahwa literasi keagamaan masyarakat di daerah 3T Kabupaten Pesisir Barat Provinsi Lampung mempunyai kesesuaian dengan sikap toleransi dengan mengacu pada lima indikator yang ditemukan antara lain aspek keyakinan, praktik, pengalaman, pengetahuan, dan pengamalan agama. ${ }^{9}$

\footnotetext{
${ }^{5}$ Esti Swatika Sari and Setyawan Pujiono, "Budaya Literasi Di Kalangan Mahasiswa FBS UNY," LITERA 16, no. 1 (June 5, 2017), https://doi.org/10.21831/ltr.v16i1.14254.

${ }^{6}$ Sri Agustin and Bambang Eko Hari Cahyono, "Gerakan Literasi Sekolah Untuk Meningkatkan Budaya Baca Di SMA Negeri 1 Geger," Linguista: Jurnal Ilmiah Bahasa, Sastra, Dan Pembelajarannya 1, no. 2 (December 29, 2017): 55-62, https://doi.org/10.25273/linguista.v1i2.1973.

${ }^{7}$ Mohammad Yamin, "Kebijakan Literasi Untuk Meningkatkan Produktivitas Publikasi Di Perguruan Tinggi," JAS-PT (Jurnal Analisis Sistem Pendidikan Tinggi Indonesia) 2, no. 1 (July 31, 2018): 19-26, https://doi.org/10.36339/jaspt.v2i1.120.

${ }^{8}$ Agus Iswanto, "Praktik Literasi Agama Pada Masyarakat Indonesia Tempo Dulu: Tinjauan Awal Atas Naskah-Naskah Cirebon," Manuskripta 8, no. 2 (December 28, 2018): 43-65, https://doi.org/10.33656/manuskripta.v8i2.114.

${ }^{9}$ Yetri Yetri, Agung M. Iqbal, and Eni Amaliah, "Literasi Keberagamaan Masyarakat Daerah 3T Di Kabupaten Pesisir Barat Serta Relevansinya Dengan Sikap Toleransi Terhadap Penganut Agama
} 
Beberapa studi di atas memperkaya khazanah kajian literasi dengan berbagai konteks dan perspektif berbeda. Akan tetapi, penulis masih mempunyai ruang untuk ikut andil dalam memperluas ruang lingkup dan area kajian yang sudah ada. Tulisan ini akan berupaya untuk menjelaskan praktik literasi agama di SMA 2 (SMADA) Kediri. SMADA merupakan sekolah berprestasi yang telah terakreditasi A dengan nilai 95 dan menjadi sekolah rujukan nasional sejak 2016. ${ }^{10}$ Guru dan siswa SMADA juga mempunyai prestasi di tingkat kota, provinsi, dan nasional. ${ }^{11}$ Selain itu, SMADA juga telah menjalankan GLS sebagai salah satu kegiatan unggulannya sejak Juli $2016 .{ }^{12}$

\section{Metode}

Tulisan ini berangkat dari penelitian lapangan dengan menggunakan jenis penelitian kualitatif dan pendekatan fenomenologi empiris. Fenomenologi memfokuskan diri pada deskripsi pengalaman bersama yang dimiliki semua partisipan atas fenomena yang mereka alami. ${ }^{13}$ Dalam kajian ini penulis mencari pengalaman bersama dari ekosistem pendidikan di SMA Negeri 2 Kediri mengenai praktik literasi agama. Pengumpulan data sebagaimana anjuran Creswell adalah dengan melakukan interviu mendalam dengan partisipan, observasi, dan dokumentasi atau jurnal. ${ }^{14}$ Dalam penelitian ini peneliti melakukan interviu dengan kepala sekolah, waka kurikulum, dan koordinator gerakan literasi membaca religius. Kemudian mengobservasi kegiatan literasi yang berlangsung dan output dari hasil literasi yang berupa karya siswa di mading dan sejenisnya. Peneliti juga menambahkan pemeriksaan dokumen seperti buku catatan atau jurnal siswa yang mereka susun berdasarkan kegitan literasi yang telah dilakukan dan memeriksa dokumen online sebagaimana tampak di web sekolah mengenai GLS di SMA Negeri 2 Kediri.

Selanjutnya data yang telah diperoleh akan dianalisis melalui lima tahapan. Pertama, horizonalization (menyoroti statemen penting dalam transkrip interviu yang

\footnotetext{
Minoritas," Al-Adyan: Jurnal Studi Lintas Agama 14, no. 2 (2019): 197-210, https://doi.org/10.24042/ajsla.v14i2.5651.

10"Prestasi Sekolah - SMA Negeri 2 Kediri," accessed November 28, 2019, https://sman2kediri.sch.id/prestasi-sekolah/.

11“Prestasi Guru - SMA Negeri 2 Kediri," accessed November 28, 2019, https://sman2kediri.sch.id/prestasi-guru/; "Prestasi Siswa - SMA Negeri 2 Kediri," accessed November 28, 2019, https://sman2kediri.sch.id/prestasi-siswa/.

12“Gerakan Literasi Sekolah SMA Negeri 2 Kediri,” accessed November 28, 2019, https://sman2kediri.sch.id/gerakan-literasi-sekolah-sma-negeri-2-kediri/.

${ }^{13}$ John W. Creswell, Qualitative Inquiry \& Research Design: Choosing among Five Approaches, 2nd ed (Thousand Oaks: Sage Publications, 2007), 57-58.

${ }^{14}$ Creswell, 61 .
} 
memberikan pemahaman tentang bagaimana partisipan mengalami suatu fenomena). Kedua, cluster of meaning (mengelompokkan pernyataan-pernyataan penting secara tematik). Ketiga, textural description (mendeskripsikan pengalaman partisipan). Keempat, structural description (mendeskripsikan konteks atau keadaan yang memengaruhi bagaimana pengalaman partisipan atas fenomena). Kelima, essentialinvariant structure (menuliskan deskripsi gabungan yang menyajikan inti dari fenomena). ${ }^{15}$

\section{Pembahasan}

\section{Perkembangan Literasi dan Makna Literasi Agama}

Istilah literasi berasal dari disiplin ilmu linguistik yang mengacu pada kemampuan untuk menggunakan bahasa yaitu untuk membaca dan mungkin untuk menuliskannya, untuk memanipulasi kosa kata, tata bahasa, dan sintaksnya. ${ }^{16}$ Melalui definisi awalnya, istilah literasi kemudian secara umum didefinisikan sebagai kemampuan atau keterampilan membaca dan menulis. Ini menegaskan bahwa orang literat adalah orang yang menguasai keterampilan berbahasa, baik dalam hal membaca maupun menulis. ${ }^{17}$ Definisi awal ini yang kemudian mengidentikkan istilah literasi dengan kemampuan membaca dan menulis. Dalam perkembangannya, istilah literasi terus mengalami dinamisasi makna. Di Indonesia, awalnya literasi dimaknai sebagai keberaksaraan yang mengarah pada usaha pemberantasan buta huruf. Kemudian istilah literasi dimaknai sebagai melek atau keterpahaman, makna melek di sini menekankan pada keterampilan berbahasa secara utuh sebagai fondasi bagi pengembangan melek dalam berbagai hal hingga mencapai tahap multiliterasi. Multiliterasi bermakna sebagai keterampilan menggunakan beragam cara untuk menyatakan dan memahami ide-ide dan informasi dengan menggunakan beragam bentuk teks baik konvensional, inovatif, simbol dan multimedia. $^{18}$

Dalam konteks GLS, literasi mencakup fondasi literasi atau literasi dasar yang terdiri dari literasi baca tulis, numerasi, sains, digital, finansial, dan literasi budayakewargaan. Selain fondasi literasi, ada tiga literasi lain yaitu literasi kesehatan, literasi keselamatan, dan literasi kriminal. Literasi juga terdiri dari keterampilan berpikir

\footnotetext{
${ }^{15}$ Creswell, 62.

${ }^{16}$ Stephen Prothero, Religious Literacy: What Every American Needs to Know--And Doesn't (HarperOne, 2009), 11.

${ }^{17}$ Gustini, Rohaniawati, and Imani, Budaya Literasi, 28.

${ }^{18}$ Satgas Gerakan Literasi Sekolah Kemendikbud, Desain Induk Gerakan Literasi Sekolah (Jakarta: Direktorat Jenderal Pendidikan Dasar dan Menengah Kementerian Pendidikan dan Kebudayaan, 2016), 7.
} 
dengan menggunakan beragam bentuk sumber pengetahuan, kemampuan ini kemudian disebut sebagai literasi informasi yang terdiri dari enam komponen, antara lain literasi dini, literasi dasar, literasi perpustakaan, literasi media, literasi teknologi dan literasi visual. $^{19}$

Pada praktiknya, GLS menekankan frekuensi membaca agar siswa mempunyai kebiasaan membaca, bukan menekankan pada durasi membaca. Dengan begitu siswa akan terbiasa membaca dan pada tahap selanjutnya kebiasaan itu berkembang menjadi suatu kegemaran atau hobi yang kemudian menjelma menjadi sebuah tradisi karena tujuan literasi adalalah pencapaian budi pekerti. Untuk mencapai tujuan itu frekuensi membaca dilakukan setiap hari dengan alokasi waktu 15 menit dan buku yang dibaca adalah buku nonteks pelajaran. Sedangkan waktu pelaksanaan yang tepat dapat dilakukan pada awal, tengah atau akhir kegiatan belajar mengajar. Banyak bentuk praktik literasi di sekolah, misalnya dapat dilihat pada salah satu hasil riset Satgas GLS yang menginformasikan bahwa di SMAN 4 Pekanbaru Riau yang menerapkan 15 menit membaca buku nonteks pelajaran setelah 15 menit membaca Al-Qur'an (siswa muslim) atau Kitab lain (siswa non muslim) dengan memajukan waktu datang ke sekolah karena total kegiatan literasi berlangsung selama 30 menit. $^{20}$ Contoh di atas menunjukkan praktik literasi yang seimbang karena sebelum kegiatan literasi 15 menit untuk membaca buku nonteks pelajaran siswa telah membaca Al-Qur'an. Kegiatan membaca Al-Qur'an di sini juga sebetulnya terkategorisasi sebagai kegiatan literasi, tepatnya literasi agama.

Dalam hal ini Prothero menjelaskan bahwa literasi agama mengacu pada kemampuan untuk memahami dan menggunakan dalam kehidupan keseharian dari blok bangunan dasar tradisi keagamaan yang mencakup konsep kunci seperti simbol-simbol, doktrin, praktik, ucapan, karakter, metafora dan narasi. Lebih lanjut Prothero juga menjelaskan bahwa literasi Islam dapat mengacu pada pengetahuan dasar sejarah Islam, praktik-praktik utama dari rukun Islam, dan simbol-simbol dasar, kepahlawanan, dan kisah-kisah Al-Qur'an. Literasi agama juga bisa mengacu pada pembagian berbagai kapasitas fungsional seperti literasi ritual, literasi pengakuan, literasi denominasi, dan

\footnotetext{
${ }^{19}$ Satgas Gerakan Literasi Sekolah Kemendikbud, 7-12.

${ }^{20}$ Billy Antoro, Gerakan Literasi Sekolah dari Pucuk hingga Akar: Sebuah Refleksi (Jakarta: Direktorat Jenderal Pendidikan Dasar dan Menengah Kementerian Pendidikan dan Kebudayaan, 2017), 34-39.
} 
literasi narasi. Sebagaimana bentuk literasi lainnya, makna literasi agama merupakan praktik yang lebih cair daripada kondisi tetap. ${ }^{21}$

Selanjutnya gagasan literasi agama ini dikembangkan oleh Gallagher. Baginya, literasi agama harus mencakup tidak hanya tingkat penguasaan informasi atau pengetahuan dasar tapi juga beberapa wawasan tentang bagaimana orang menggunakan pengetahuan dasar itu untuk mengorientasikan diri mereka di dunia, mengekspresikan pemahaman diri individual dan komunal mereka, dan memberikan arah dan makna bagi hidup mereka. Untuk menjadi literat soal agama, seseorang perlu mengetahuai sesuatu tentang dinamika agama, mekanisme, dan proses tentang bagaimana beragama. ${ }^{22}$ Penjelasan ini sejalan dengan pendapat Fujiwara yang menyatakan bahwa literasi agama seharusnya bukan semata-mata akumulasi pengetahuan tentang tradisi agama, tetapi lebih pada sebuah kemampuan untuk menggunakan pengetahuan tersebut untuk mereaksi secara aktif dan tepat atas persoalan agama yang sebenarnya. ${ }^{23}$ Dengan begitu, konsep literasi agama mempunyai makna dan ruang lingkup yang sangat luas dan terbentang dari hal yang sederhana hingga hal rumit mulai dari pengetahuan, pemahaman, penafsiran, praktik, pengalaman, pengamalan, tradisi keagamaan dan beragam aspek lain dari agama. Literasi agama juga menekankan bagaimana penganut agama dapat menjadikan agama sebagai pedoman hidup dan mampu menjawab berbagai problem, bukan malah melahirkan problem sosial dan kemanusiaan dengan mengatasnamakan agama.

\section{Praktik Literasi Agama di SMA Negeri 2 Kediri}

SMA Negeri 2 (SMADA) Kediri telah menerapkan program literasi sejak Juli 2016. Berkenaan dengan itu Lukito selaku Waka Kurikulum menuturkan bahwa pada awalnya bentuk literasi mengarah pada kegiatan membaca buku nonteks pelajaran yang dimaksudkan untuk menambah wawasan siswa. Kegiatan ini telah berlangsung selama tiga tahun. Program ini juga mendorong inisiatif siswa untuk membentuk small group dengan kegiatan rutinnya berupa diskusi. Selain itu, output kegiatan literasi juga tampak dari hasil karya siswa yang dikemas dalam bentuk majalah dinding yang diletakkan di penjuru sekolah. Untuk lebih mengoptimalkan kegiatan literasi, sekolah mengadakan

\footnotetext{
${ }^{21}$ Prothero, Religious Literacy: What Every American Needs to Know--And Doesn't, 11-14.

${ }^{22}$ Eugene V. Gallagher, "Teaching for Religious Literacy," Teaching Theology \& Religion 12, no. 3 (July 2009): 208-21, https://doi.org/10.1111/j.1467-9647.2009.00523.x.

${ }^{23}$ Satoko Fujiwara, "On Qualifying Religious Literacy: Recent Debates on Higher Education and Religious Studies in Japan," Teaching Theology \& Religion 13, no. 3 (2010): 223-36, https://doi.org/10.1111/j.1467-9647.2010.00615.x.
} 
beberapa kegiatan pendukung seperti lomba pojok, lomba partisipan GLS terbaik dan lomba menulis cerpen. Dari kegiatan literasi itu dan program penunjang lainnya siswa menjadi lebih bersemangat dalam membaca.

Selanjutnya perkembangan kegiatan literasi saat ini mengalami perubahan. Sony Tataq Setya Suwasono selaku Kepala Sekolah menjelaskan bahwa bentuk literasi di SMADA berubah dan mengarahkan kegiatannya pada literasi agama. Rencana ini telah menjadi wacana sekolah sejak tahun lalu. Namun baru dapat memulainya pada tahun ajaran 2019-2020 sesuai hasil kesepakatan rapat seluruh komponen yang ada di SMADA Kediri. Sederhananya kegiatan literasi agama dimulai dengan mengubah kegitan literasi membaca buku nonteks pelajaran menjadi membaca Al-Qur'an atau Kitab agama lain sesuai dengan agama yang dianut siswa. Perubahan ini merupakan bentuk dinamika yang disesuaikan dengan kebutuhan sekolah yang juga berkaitan dengan pelaksanaan kurikulum 2013, di mana salah satu poin pentingnya adalah penguatan pendidikan karakter. Di samping itu, perubahan bentuk literasi ini juga berkaitan erat dengan visi SMADA untuk mewujudkan manusia Indonesia yang berkarakter unggul.

Untuk mengoptimalkan kegiatan literasi yang saat ini mengarah pada literasi agama, Kepala Sekolah menerapkan beberapa cara atau proses implementasi. Pertama, kepala sekolah membentuk tim literasi religius. Tim ini yang kemudian dijadikan sebagai pionir literasi agama yang dibantu oleh seluruh guru. Keberadaan tim ini menjadi penting karena mempertimbangkan sekaligus sebagai antisipasi atas beberapa siswa yang daya membacanya masih rendah. Problem ini kemudian akan ditindak lanjuti dengan memberikan bimbingan yang lebih intensif. Tim literasi ini berbentuk struktur organisasi yang terdiri dari kepala sekolah, komite sekolah, kepala tata usaha/wakil bidang tata usaha, wakil kepala sekolah terdiri dari wakil kepala sekolah bidang kurikulum, humas, sarpras, kesiswaan dan guru agama.

Tim literasi religius di SMA 2 Kediri menjadi salah satu indikator penting kemajuan gerakan literasi sekolah. Adanya tim literasi religius menunjukkan peran kepala sekolah sebagai driver yang berfungsi sebagai pengendali bagi guru-guru bekerja bersamanya. ${ }^{24}$ Tim ini juga menunjukkan bahwa semua komponen warga sekolah telah bersinergi di bawah koordinasi kepala sekolah untuk membuat perencanaan, pelaksanaan dan penilaian program literasi. Dengan begitu, keberadaan tim ini dapat

\footnotetext{
${ }^{24}$ Antoro, Gerakan literasi sekolah dari pucuk hingga akar, 62.
} 
dijadikan sebagai sarana untuk memastikan program literasi agama berjalan sesuai dengan rencana dan memastikan suasana akademik yang kondusif bagi ekosistem pendidikan. Karena subjek literasi bukan hanya siswa tapi seluruh warga sekolah yang mencakup pendidik, tenaga kependidikan, dan kepala sekolah. ${ }^{25}$

Selanjutnya adalah tahap implementasi. Pada dasarnya tahapan implementasi yang diterapkan pada literasi agama ini tidak jauh berbeda dengan literasi membaca pada tahun-tahun sebelumnya, yaitu pembiasaan. Sebelumnya taraf pembiasaan ini dilaksanakan pada awal kegiatan belajar mengajar sebelum pelajaran dimulai dan berlangsung selama 15 menit pada hari Senin sampai Jumat dengan bimbingan dan pengawasan guru yang mengajar pada jam pertama. Ini dilakukan agar siswa mempunyai niat dan kemauan membaca tanpa paksaan atau karena diminta oleh guru. Sedangkan untuk kegiatan literasi saat ini, perubahannya tampak dari kegiatan literasi yang lebih mengarah pada praktik keagamaan seperti membaca Al-Qur'an, belajar tilawah dengan baik dan benar serta membaca terjemahnya.

Berkenaan dengan implementasinya, Abdul Karim selaku guru agama sekaligus Koordinator Gerakan Membaca Religius menjelaskan bahwa secara teknis kegiatan literasi agama dilaksanakan secara bersamaan yang dipimpin oleh tiga sampai lima orang siswa yang ditunjuk secara bergiliran. Kegiatan membaca Al-Qu'an dengan cara terpimpin atau terpandu (guided reading) ini dilakukan secara terpusat di ruang Waka Kurikulum sedangkan siswa lain mendengarkan serta mengikuti di dalam kelasnya masing-masing dengan cara membaca bersama (shared reading). Siswa non muslim juga melaksanakan kegitan literasi agama. Teknisnya adalah dengan mengumpulkan mereka di tempat yang sudah disiapkan atau ruang khusus untuk kegiatan literasi religius. Di sana mereka akan dibimbing oleh guru pendamping bimbingan rohani dari masing-masing agama. Setelah kegiatan itu mereka kembali ke kelas masing-masing untuk melaksanakan kegiatan pembelajaran seperti biasa.

Penjelasan di atas menunjukkan bahwa program literasi agama di SMA Negeri 2 Kediri berlangsung sesuai dengan tahap-tahap pelaksanaan literasi di sekolah yang mencakup tahap pembiasaan, pengembangan, dan pembelajaran. ${ }^{26}$ Tahap pembiasaan tampak dari partisipasi guru dalam kegiatan literasi dengan tanpa memberikan intervensi apapun. Pada tahap pengembangan, partisipasi guru semakin tampak dalam mendorong siswa untuk bersikap aktif dan produktif. Ini dapat dilihat dari buku catatan

\footnotetext{
${ }^{25}$ Satgas Gerakan Literasi Sekolah Kemendikbud, Desain Induk Gerakan Literasi Sekolah, 13.

${ }^{26}$ Antoro, Gerakan literasi sekolah dari pucuk hingga akar, 41-43.
} 
atau portofolio yang dibuat siswa berdasarkan kegiatan literasi yang telah dilakukan. Hasilnya semakin terlihat pada hasil karya dan prestasi siswa pada event literasi yang diadakan sekolah.

Tahapan terakhir adalah penilaian. Pada praktiknya tahap penilaian ini berlangsung dengan mengadakan event literasi seperti lomba membaca Al-Qur'an putra putri literasi. Event ini juga dimaksudkan sebagai bentuk apresiasi atas partisipasi siswa dan mendorong semangat mereka agar semakin literat. Bentuk lainnya adalah buku catatan atau jurnal yang dikemas oleh para siswa dan siswi yang diambil dari kegiatan literasi agama yang telah dilakukan. Meski begitu, proses pelaksanaan literasi agama di SMADA bukan tanpa hambatan. Dalam hal ini Sony Tataq Setya Suwasono mengungkapkan bahwa terkait hambatan yang kami rasakan saat ini, yang pertama masih ada siswa yang terlambat ketika kegiatan literasi dimulai. Untuk mengatasi hambatan ini kami memberikan sanksi pada mereka. Bentuk sanksi yang diberikan seperti halnya menulis surat Yasin dan membaca Istighfar seribu kali. Sanksi ini diberikan untuk membuat peserta didik jera dan dengan hukuman itu juga diharapkan mereka mampu menyadari kesalahannya. Hambatan kedua adalah masih belum ada perpustakaan mini di setiap sudut-sudut kelas untuk menunjang kegiatan literasi membaca.

Tahap penilaian memainkan peran penting dalam kegiatan literasi sekolah. Dengan tahapan ini tim gerakan membaca religius dan semua guru dapat mengetahui progress siswa dalam kegiatan literasi agama yang telah dilakukan baik dalam hal pengetahuan dasar maupun pada tataran praktiknya. Dengan kata lain, penerapan literasi agama tidak hanya mengarah pada aspek pengetahuan dasar agama semata, melainkan mengupayakannya pada tataran praktik dengan membiasakan siswa untuk membaca AlQur'an atau Kitab Suci lain sesuai agama yang dianut. Keadaan ini menunjukkan kesesuaian antara praktik literasi agama di sekolah dengan makna literasi agama sebagai penguasaan pengetahuan agama dan memanfaatkan pengetahuan itu dalam kehidupan keseharian sehingga dapat dijadikan media ekspresi diri serta memberikan arah dan makna hidup. ${ }^{27}$

Penilaian juga bermanfaat untuk mengetahui antusiasme siswa dan sebagai bahan evaluasi untuk meningkatkan kualitas program literasi agama. Selain itu, solusi atas hambatan yang ditemukan dalam proses pelaksanaan program literasi agama dapat

\footnotetext{
${ }^{27}$ Prothero, Religious Literacy: What Every American Needs to Know-And Doesn't, 11-12; Gallagher, "Teaching for Religious Literacy"; Fujiwara, "On Qualifying Religious Literacy." 
dijadikan sarana untuk meningkatkan kualitas karakter siswa yaitu, kedisiplinan. Ini juga menunjukkan bahwa program literasi agama sejalan dengan konsep kurikulum terutama dalam hal peningkatan pendidikan karakter. Selain itu, program literasi ini juga dapat dikembangkan untuk mengedukasi siswa agar mempunyai pemahaman agama yang inklusif dan moderat. Ini menjadi penting untuk membentengi siswa dari kuatnya arus gerakan radikalisme agama yang sudah merambah hampir pada berbagai jenjang pendidikan dengan pola gerakan dan pendekatan yang semakin samar.

Uraian di atas menginformasikan bahwa pelaksanaan program literasi agama di SMA Negeri 2 Kediri berada dalam koridor GLS. Ini dapat dilihat dari tahap-tahap pelaksanaannya dan telah memenuhi prinsip-prinsip literasi sekolah. ${ }^{28}$ Pertama, berlangsung sesuai dengan tahap perkembangan yang dapat diprediksi dengan memilih strategi pembiasaan dan pembelajaran yang sesuai. Kedua, program literasi agama juga berlangsung seimbang, artinya semua siswa berpartisipasi dalam kegiatan literasi sesuai dengan agama yang dianut. Ketiga, terintegrasi dengan kurikulum yang berarti bahwa pembiasaan dan pembelajaran literasi merupakan tanggung jawab semua guru. Keempat, terlihat dari hasil karya dan prestasi siswa dalam berliterasi. Kelima, mengembangkan budaya lisan yang tampak dari munculnya inisiatif siswa membentuk small group dan partisipasi siswa pada event-event literasi agama yang diselenggarakan sekolah. Keenam, pengembangan kesadaran warga sekolah dalam menghargai perbedaan melalui kegiatan literasi. Ini juga tampak dari upaya tim gerakan membaca religius yang mengakomodasi semua siswa yang berbeda agama dalam mengikuti kegiatan literasi agama.

Pengembangan praktik literasi sekolah dalam bentuk literasi agama menjadi penting karena sangat berkaitan dengan penguatan pemahaman keagamaan siswa dan bagaimana mereka mempraktikkan pengetahuan agama yang telah diperoleh. Dengan begitu siswa dapat mempelajari agama lebih intens dan berfrekuensi. Praktik literasi agama juga secara tidak langsung telah membantu memaksimalkan pelajaran agama di sekolah karena mata pelajaran agama di sekolah seringkali dikaitkan dengan problem jam pelajaran yang singkat dan membosankan.

Di samping itu, pada tahap selanjutnya kegiatan literasi agama juga dapat diarahkan pada perluasan wawasan agama yang moderat dan inklusif karena makna literasi agama pada konteks awalnya diarahkan untuk tidak mempertentangkan agama

\footnotetext{
${ }^{28}$ Satgas Gerakan Literasi Sekolah Kemendikbud, Desain Induk Gerakan Literasi Sekolah, 13-14.
} 
dengan negara dalam konteks negara sekular. Saat ini masih banyak negara sekular yang tengah berjuang dalam mereformasi pendidikan nasionalnya untuk memasukkan pendidikan agama di sekolah. ${ }^{29}$ Ini juga menjadi pembeda praktik literasi agama di Indonesia dengan negara sekular karena dalam sistem pendidikan Indonesia, pendidikan agama telah terintegrasi dalam pendidikan nasional dan mempunyai dasar hukum yang kuat sebagaimana tercantum dalam Undang-Undang Pendidikan Nasional. Inilah yang menjadi dasar pendidikan agama masuk pada semua jenjang pendidikan di Indonesia.

\section{Kesimpulan}

Literasi agama di SMA Negeri 2 Kediri merupakan pengembangan dari literasi baca tulis yang telah berlangsung sejak tahun 2016. Program ini dilaksanakan dengan cara membaca Al-Qur'an bagi siswa muslim secara bersama-sama dengan dipandu oleh siswa yang telah ditunjuk. Bagi siswa non muslim, kegiatan membaca kitab sesuai dengan agamanya dengan dipandu seorang rohaniawan. Siswa yang telat atau tidak melakukan kegiatan ini akan mendapat sanksi berupa menulis surat Yasin atau membaca Istighfar sebanyak seribu kali. Kegiatan literasi agama ini dilakukan melalui pembiasaan yang teratur sehingga diharapkan membentuk karakter pribadi yang luhur. Kepala Sekolah juga telah menunjuk tim khusus untuk memantau progress literasi agama siswa serta mengevaluasi hambatan-hambatan yang terjadi sehingga program literasi agama ini dapat berkembang sesuai yang diharapkan.

\section{Daftar Pustaka}

Agustin, Sri, and Bambang Eko Hari Cahyono. "Gerakan Literasi Sekolah Untuk Meningkatkan Budaya Baca Di SMA Negeri 1 Geger." Linguista: Jurnal Ilmiah Bahasa, Sastra, Dan Pembelajarannya 1, no. 2 (December 29, 2017): 55-62. https://doi.org/10.25273/linguista.v1i2.1973.

Antoro, Billy. Gerakan Literasi Sekolah dari Pucuk hingga Akar: Sebuah Refleksi. Jakarta: Direktorat Jenderal Pendidikan Dasar dan Menengah Kementerian Pendidikan dan Kebudayaan, 2017.

Creswell, John W. Qualitative Inquiry \& Research Design: Choosing among Five Approaches. 2nd ed. Thousand Oaks: Sage Publications, 2007.

Dinham, Adam, and Martha Shaw. "Religious Literacy through Religious Education: The Future of Teaching and Learning about Religion and Belief." Religions 8, no. 7 (July 2017): 119. https://doi.org/10.3390/rel8070119.

\footnotetext{
${ }^{29}$ Adam Dinham and Martha Shaw, "Religious Literacy through Religious Education: The Future of Teaching and Learning about Religion and Belief," Religions 8, no. 7 (July 2017): 119, https://doi.org/10.3390/rel8070119; Prothero, Religious Literacy: What Every American Needs to Know-And Doesn't.
} 
Fujiwara, Satoko. "On Qualifying Religious Literacy: Recent Debates on Higher Education and Religious Studies in Japan." Teaching Theology \& Religion 13, no. 3 (2010): 223-36. https://doi.org/10.1111/j.1467-9647.2010.00615.x.

Gallagher, Eugene V. "Teaching for Religious Literacy." Teaching Theology \& Religion 12, no. 3 (July 2009): 208-21. https://doi.org/10.1111/j.14679647.2009.00523.x.

“Gerakan Literasi Sekolah SMA Negeri 2 Kediri." Accessed November 28, 2019. https://sman2kediri.sch.id/gerakan-literasi-sekolah-sma-negeri-2-kediri/.

Gustini, Neng, Dede Rohaniawati, and Anugrah Imani. Budaya Literasi (Model Pengembangan Budaya Baca Tulis Berbasis Kecerdasan Majemuk Melalui Tutor Sebaya). Yogyakarta: Deepublish, 2016.

Iswanto, Agus. "Praktik Literasi Agama Pada Masyarakat Indonesia Tempo Dulu: Tinjauan Awal Atas Naskah-Naskah Cirebon." Manuskripta 8, no. 2 (December 28, 2018): 43-65. https://doi.org/10.33656/manuskripta.v8i2.114.

OECD. PISA 2015 Results (Volume I): Excellence and Equity in Education. PISA. OECD, 2016. https://doi.org/10.1787/9789264266490-en.

. PISA 2018 Results (Volume I): What Students Know and Can Do. PISA. OECD, 2019. https://doi.org/10.1787/5f07c754-en.

"Prestasi Guru - SMA Negeri 2 Kediri." Accessed November 28, 2019. https://sman2kediri.sch.id/prestasi-guru/.

"Prestasi Sekolah - SMA Negeri 2 Kediri." Accessed November 28, 2019. https://sman2kediri.sch.id/prestasi-sekolah/.

"Prestasi Siswa - SMA Negeri 2 Kediri." Accessed November 28, 2019. https://sman2kediri.sch.id/prestasi-siswa/.

Prothero, Stephen. Religious Literacy: What Every American Needs to Know--And Doesn't. HarperOne, 2009.

Sari, Esti Swatika, and Setyawan Pujiono. "Budaya Literasi Di Kalangan Mahasiswa FBS UNY." LITERA 16, no. 1 (June 5, 2017). https://doi.org/10.21831/ltr.v16i1.14254.

Satgas Gerakan Literasi Sekolah Kemendikbud. Desain Induk Gerakan Literasi Sekolah. Jakarta: Direktorat Jenderal Pendidikan Dasar dan Menengah Kementerian Pendidikan dan Kebudayaan, 2016.

"Tentang GLN | Gerakan Literasi Nasional." Accessed November 27, 2019. https://gln.kemdikbud.go.id/glnsite/tentang-gln/.

Yamin, Mohammad. "Kebijakan Literasi Untuk Meningkatkan Produktivitas Publikasi Di Perguruan Tinggi." JAS-PT (Jurnal Analisis Sistem Pendidikan Tinggi Indonesia) 2 , no. 1 (July 31, 2018): 19-26. https://doi.org/10.36339/jaspt.v2i1.120.

Yetri, Yetri, Agung M. Iqbal, and Eni Amaliah. "Literasi Keberagamaan Masyarakat Daerah 3T Di Kabupaten Pesisir Barat Serta Relevansinya Dengan Sikap Toleransi Terhadap Penganut Agama Minoritas." Al-Adyan: Jurnal Studi Lintas Agama 14, no. 2 (2019): 197-210. https://doi.org/10.24042/ajsla.v14i2.5651. 